\title{
Yükseköğretimdeki Suriyeli Sığınmacı Öğrenciler: Uyum ve Çatışma Alanları
}

\section{Social Cohesion and Conflict Areas of Syrian Asylum Seeker Students in Higher Education}

\section{Hakan GÜLERCE ${ }^{(*)}$, Rukiye ÇORLU ${ }^{* *}$}

\section{$\ddot{0} z$}

Türkiyéde yükseköğretimdeki Suriyeli öğrenci sayısı her geçen yıl artmaktadır. 20192020 ögretim yılında bu sayı Türkiye'de 37.236'e ulaşmışır. Harran Üniversitesi bu dönemde 2.677 Suriyeli ögrencisi ile 209 üniversite arasında en fazla Suriyeli öğrencinin öğrenim gördüğü üniversite olarak birinci sırada yer almaktadır. Göçün doğasında bulunan en temel olgulardan birisi de göç eden ve onları misafir eden yerel halkların yaşamış oldukları insani karşılaşmadır. Bu karşılaşmadan her iki toplum çeşitli açılardan etkilenmektedir. Bu çalışmada, Suriyeli sığınmacı yükseköğretim öğrencilerinin ögrenim hayatları boyunca karşılaştıkları sosyal dâhil edilme sorunları ön plana çıkarılmış, Harran Üniversitesi'nde öğrenim gören Suriyeli öğrencilerin sosyal deneyimleri ve karşılaş̧ıkları sorunlar üzerine bir değerlendirme yapılmıştır. Bu amaçla her birinde altı kişilik katıllmcı olmak kaydıyla iki odak grup görüşmesi gerçekleştirilmiştir. Odak grup görüşmelerinde elde edilen veriler kabullenme, toplumsal etkileşim, belirsizlik, yabanctlik, damgalanma, ötekileştirme gibi çeşitli temel sorunlar çerçevesinde analiz edilmiştir.

Özgün Araştırma Makalesi (Original Research Article)

Geliş Tarihi: 05.01.2021 Kabul Tarihi: 05.04.2021

${ }^{(*)}$ Dr. Öğr. Üyesi, Harran Üniversitesi, Fen Edebiyat Fakültesi Sosyoloji Bölümü, hakangulerce@ harran.edu.tr

ORCID ID: https://orcid.org/0000-0003-3601-5725

${ }^{(*)}$ Lisans Öğrencisi, Harran Üniversitesi, Fen Edebiyat Fakültesi, Sosyoloji Bölümü. Milli Eğitim Bakanlığı, Öğretmen., rcorluu@gmail.com

ORCID ID: https://orcid.org/0000-0002-1683-7337 


\section{Hakan GÜLERCE ve Rukiye ÇORLU}

Suriyeli ögrencilerin topluma dâhil olma ve birlikte yaşama isteklerinin yüksek olduğu ancak bununla birlikte ötekileştirme, dişlanma, psiko-sosyal destekten mahrum kalma gibi sorunları farklı biçimlerde yaşamaya devam etmeleri bu çalı̧̧manın ana sorunsalın oluşturmaktadır.

Anahtar Kelimeler: Zorunlu Göç, Siğınmacılar, Suriyeli Üniversite Öğrencileri, Sosyal Uyum, Yüksekögretim.

\section{Abstract}

The number of Syrian students in higher education in Turkey is increasing every year. In the 2019-2020 academic year, this number has reached 37,236. During this period, Harran University ranks first among 209 universities with 2,677 Syrian students, with the highest number of Syrian students studying in the university. One of the most fundamental facts inherent in migration is the human encounter experienced

Üsküdar University Journal of Social Sciences, 2021; issue: 12 , 71-106 by the migrants and host communities. Both communities are affected by this encounter in various ways. In this study, social inclusion problems faced by Syrian asylum seeker higher education students throughout their education and daily life have been highlighted, and an evaluation has been made on the social experiences and problems faced by Syrian students studying at Harran University. For this purpose, two focus group meetings were held, each with six participants. The data obtained from focus group interviews were analyzed within the framework of various basic problems such as acceptance, social interaction, uncertainty, foreignness, stigmatization, and marginalization. The main problem of this study is that Syrian students have a high desire to participate in society and live together, but they continue to experience problems such as marginalization, exclusion, and deprivation of psycho-social support in different ways.

Keywords: Forced Migration, Asylum Seekers, Syrian University Students, Social Cohesion, Higher Education.

\section{Giriş}

Suriye'de devam eden iç savaş nedeniyle yüzbinlerce insan sınır ötesi göçe maruz kalarak yerlerinden edilmiştir. $\mathrm{Bu}$ zorunlu ve kitlesel göç çoğunlukla Suriye'nin çevre ülkelerine yönelik gerçekleşmiştir. Sayıca en fazla göç alan ülke konumunda olan Türkiye, Göç İdaresi Genel Müdürlüğü verilerine göre 3.639.572 sayısı ile dünyada en fazla Suriyeli sığınmacıya ev 


\section{Yükseköğretimdeki Suriyeli Sığınmacı Öğrenciler: Uyum ve Çatışma Alanları}

sahipliği yapan ülke konumundadır.' Bununla birlikte Türkiye'de yaşayan Suriyelilerin büyük çoğunluğu Suriye'ye sınır illere yerleşmişlerdir. Bugün Türkiye'de geçici koruma kapsamındaki Suriyelilerin 142.676'1 geçici barınma merkezlerinde, $3.501 .666^{\prime} 1$ da çeşitli illerde yaşamaktadır. $\mathrm{Bu}$ illerin başında 517,916 sı̆̆ınmacı ile İstanbul, 449,411 sı̆̆ınmacı ile Gaziantep, 433,265 sığınmacı ile Hatay ve 452.534 sığınmacı ile Şanlıurfa yer almaktadır.

Suriye'den Türkiye'ye toplu halde ilk girişin yaşandığı Mart 2011 ve takip eden ilk aylarda "geçici misafirler" olarak isimlendirilen Suriyelilerin, iç savaşın uzamasıyla en azından uzun bir süre Türkiye'de kalacakları açıkça anlaşılmıştır. Bununla birlikte her ne kadar genel kanı zorla yerinden edilerek kitlesel göçe maruz kalan ve uzun süre bir ülkede yaşayan insanların ülkelerine geri dönmeyeceği yönünde ise de Suriyelilerin Türkiye'de kalış, geri dönüş veya başka bir ülkeye gidiş planları konusunda kesin bir yargıya varmak mümkün değildir.

Türkiye’de geçici koruma statüsü verilen Suriyelilerin sayısı Aralık 2020 itibariyle 3,638,104 olup bu sayının 511,428'ini 19-24 yaş aralığındaki yükseköğretime devam etmesi gereken gençler oluşturmaktadır. Suriyeli gençlerin yükseköğretime katılımı konusunda Yükseköğretim Kurulu Başkanlığı olağanüstü bir çaba göstermektedir. 2018-2019 öğretim yılında 27.034 Suriyeli öğrenci yükseköğretimde kayıtlı iken bu sayı 2019-2020 öğretim yılında 37.236'e ulaşarak bir yılda önemli bir artı̧s sağlanmıştır. Bu sayıya Türk Vatandaşlığına geçen Suriyeli öğrencilerin dâhil olmadığı göz önüne alınırsa sayının daha da yüksek olduğu ortaya çıkmaktadır. ${ }^{2}$ Harran Üniversitesi, diğer üniversiteler arasında Türkiye'de 2018-2019 ögretim yllında 2.564 ve 2019-2020 öğretim yllında ise 2677 sığınmacı

\footnotetext{
1 “Göç İdaresi Genel Müdürlüğü,” Geçici Koruma, 23 Aralık 2020, https://www.goc.gov. tr/gecici-koruma5638.

2 “Yükseköğretim Bilgi Yönetim Sistemi,” erişim 26 Aralık 2020, https: / /istatistik.yok. gov.tr/
} 


\section{Hakan GÜLERCE ve Rukiye ÇORLU}

öğrenciyle birinci sırada yer almaktadır. Türkiye'de Suriyeli öğrencilerin yükseköğretime katılımlarının artmasıyla birlikte göçün beraberinde getirdiği insani karşılaşmalardan kaynaklanan uyum ve çatışma alanları da daha belirgin hale gelmektedir.

Sığınmacı ve onları misafir eden yerel halkların karşılaşma yaşaması ve bu karşılaşmanın her iki tarafa belirli sorumluluklar getirmesi göçün doğasında olan bir olgudur. Bu bağlamda Suriye'den Türkiye'ye olan kitlesel zorunlu göçün toplumsal, sosyal, ekonomik, siyasi ve güvenlik bağlamında etkileri ortaya çıkmıştır. Yaşanan bu sorunların başında toplumsal uyum gelmektedir. Suriyeliler ile yerel halk arasinda var olan farklı yaşam koşulları, dil ve kültür farklılıkları, yerel halk ile sığınmacılar arasında gerilimlere neden olabilmektedir. ${ }^{3} \mathrm{Bu}$ çalışmanın amacı her geçen

Üsküdar University Journal of Social Sciences, 2021; issue: 12 , 71-106 gün daha da önemli bir hale gelen sığınmacı öğrencilerin toplumsal olarak dâhil edilmesi ve bu süreçte karşılaşılan sorunların Suriyeli sığınmacı öğrenciler özelinde değerlendirilerek bu konuda henüz gelişmekte olan literatüre katkıda bulunmaktır. Çalışma, Zygmunt Bauman'ın kabullenme, belirsizlik, toplumsal etkileşim, etiketleme ve ötekileştirme kavramları üzerine inşa edilerek Suriyeli öğrencilerin yaşadıkları sosyal katılım deneyimlerinde ortaya çıan sorunları analiz etmeyi hedeflemektedir.

\section{Literatür}

Türkiye'de yükseköğretimdeki Suriyeli sığınmacı öğrenciler üzerine çeşitli alanlarda birçok çalışma yapılmıştır. Farklı metodolojik yaklaşımlarla ele alınan bu çalışmalar genel olarak öğrencilerin karşılaştıkları sosyal, kültürel ve dilsel uyum zorlukları üzerinde durmuştur.

Günnur Ertong Attar, çalışmasında Suriye ve Türkiye vatandaşı öğrencilerin birlikte yaşama pratiklerini özellikle iletişim kurmaktan çekinmeleri, mekânsal ayrışma, bilinmeyenle etkileşim kurma ve ön yargı

\footnotetext{
${ }^{3}$ Naim Gök, “Suriye Krizi’nin Türkiye’ye Yansımaları (2011-2017),” Üsküdar Üniversitesi Sosyal Bilimler Dergisi, sayı: 8 (Mayıs 2019): 106.
} 


\section{Yükseköğretimdeki Suriyeli Sığınmacı Öğrenciler: Uyum ve Çatışma Alanları}

bağlamında ele almıştır. Suriyeli öğrencilerin, karşılaşmış oldukları tüm olumsuz durumlara rağmen geleceğe umutla baktıkları, eğitim-öğretim hayatları ve sonrası için motive oldukları belirlenmiştir. ${ }^{4}$ Nazife Karadağ yükseköğretimdeki Suriyeli öğrencilerin uyumunu üniversitelerin sağladığı rehberlik hizmetler, sosyal faaliyetler, Türkçe öğretimi süreci gibi açılardan ele almıştır. Bu bağlamda Suriyeli öğrencilerin hocalarından destek gördükleri, fakat kendilerine yönelik sosyal faaliyetlerin yetersiz olduğu, dil yetersizliğine bağlı olarak sosyal, kültürel ve eğitim hayatlarında çeşitli sıkıntılar yaşadıkları sonucuna ulaşılmıştır. ${ }^{5}$ Çopur ve Demirel'in çalışmasında Suriyeli mültecilerin yükseköğrenim sorununu göç süreci ve sonrası bağlamında değerlendirerek bir karşılaştırma yapılmıştır. Yapılan çalışmada göç süreciyle birlikte öğrencilerin eğitim hayatlarının kesintiye uğradığı, akademik başarının azaldığı, bazı öğrencilerin eğitimlerini tamamen bırakmakzorundakaldıkları, dilin eğitim hayatlarındaki en büyük faktörlerden biri olduğu, yaşamış oldukları uyum problemlerinin eğitim hayatlarını olumsuz etkilediği tespit edilmiştir. ${ }^{6}$ Yapılan çalışmalardan da anlaşılacağı üzere Suriyeli üniversite öğrencilerinin toplumsal uyum ve birlikte yaşama pratiklerinin hem sığınmacılar hem de yerel kurumlar açısından birçok yönü bulunmaktadır.

Yükseköğretimdeki Suriyeli sığınmacı öğrenciler üzerine Türkiye’de çeşitli üniversitelerde yüksek lisans çalışmaları da yapılmıştır. Ankara'da öğrenim gören üniversite öğrencilerinin uyumuna yönelik hazırlamış

\footnotetext{
${ }^{4}$ Günnur Ertong Attar ve Deniz Küçükşen, “Somehow Familiar but Still a Stranger: Syrian Students in Turkish Higher Education”, Journal of International Migration and Integration 20, say1: 4 (1 Kasım 2019): 1041-1053, https://doi.org/10.1007/s12134-018-00647-8

${ }^{5}$ Nazife Karadağ, “Yükseköğretimde Uluslararasılaşma Bağlamında Türkiye’de Eğitim Gören Suriyeli Öğ”, Journal of Turkish Studies 11, sayı: 19 (1 Ocak 2016): 477-490, https:// doi.org/10.7827/TurkishStudies.11155

${ }^{6}$ Ahmet Çopur ve Muammer Demirel, “Suriyeli Mültecilerin Yükseköğrenim Sorunu: Göç Süreci ve Sonrası”, 2016, https://avesis.uludag.edu.tr/yayin/74a07545-d673-494db498-c7d13b2cd7a1/egitim-bilimlerinde-yenilikler-ve-nitelik-arayisi
}

Üsküdar Üniversitesi Sosyal Bilimler Dergisi, 2021;

sayl: 12 , $71-106$ 


\section{Hakan GÜLERCE ve Rukiye ÇORLU}

olduğu "Geçici Koruma Statüsünde Bulunan Suriyeli Üniversite Öğrencilerinin Göç Sürecindeki Uyum Yaşantıları” başlıklı çalışmasında Özgür Salih Kaya, Suriye’deki yaşam, Türkiye’ye geçiş süreci, Türkiye'de uyum ve üniversite yaşamını ele almaktadır. Yapılan çalışmada Kaya, Suriyeli yükseköğretim öğrencilerinin uyumunda risk faktörlerinin, koruyucu faktörlerin, gelecekle ilgili düşüncelerin ve dayanıklılığın etkili olduğunu saptamıştır.' Nihal Açıkel çalışmasında, İstanbul'daki Suriyeli üniversite gençliğinin eğitim ve meslek hayatlarını, sosyal hayatlarını, uyum süreçlerini ve gelecek beklentilerini incelemiştir. Suriyeli yükseköğretim öğrencilerinin üniversiteye giriş, dersleri saydırma ve denklik sürecinde çeşitli zorluklarla karşılaştıklarını, eğitim-öğretim

Üsküdar University Journal of Social Sciences, 2021; issue: 12 , 71-106 sürecinde dilden kaynaklanan sorunlar yaşadıklarını tespit etmiştir. $\mathrm{Bu}$ olumsuzluklara rağmen katılımcıların üniversiteyi, kendileri için en rahat yer olarak görmeleri ve sahip olunan bazı önyargıların kırıldığı diğer önemli sonuçlardandır. ${ }^{8}$ Rukiye Uçar'ın çalışması ise Suriyeli üniversite öğrencilerinin maruz kaldıkları zorunlu göçün Türkiye'deki eğitim ve uyumu üzerindeki etkilerini kültürlerarası uyum bağlamında ele almaktadır. Öğrencilerin, üniversitelerin psikolojik danışma hizmetlerinden, kulüplerden ve dil desteğinden yararlandıkları, zaman zaman iletişim eksikliği yaşadıkları, uyum konusunda çeşitli problemlerle karşılaştıkları tespit edilmiştir. ${ }^{9}$ Görüldüğü üzere her üç yüksek lisans tezi de 2019 yılında tamamlanmıştır. Bu bağlamda kitlesel Suriye zorunlu

${ }^{7}$ Özgür Salih Kaya, "Geçici Koruma Statüsünde Bulunan Suriyeli Üniversite Öğrencilerinin Göç Sürecindeki Uyum Yaşantıları,” (Yüksek Lisans Tezi, Ankara, Hacettepe Üniversitesi, 2019).

${ }^{8}$ Nihal Açıkel, “İstanbul'daki Suriyeli Üniversite Gençliği Üzerine Nitel Bir Araştırma” (Yüksek Lisans Tezi, İstanbul, İstanbul Üniversitesi, 2019).

${ }^{9}$ Rukiye Uçar, "Intercultural communication and adaptation of Syrian University students: A study at a foundation university in Istanbul," (Yüksek Lisans Tezi, İstanbul, Yıldız Teknik Üniversitesi, 2019). 


\section{Yükseköğretimdeki Suriyeli Sığınmacı Öğrenciler: Uyum ve Çatışma Alanları}

göçünün onuncu yılı olduğu göz önüne alındığında yapılan çalışmaların hala sınırlı sayıda olduğu ve yeni çalışmaların gerekliliği aşikârdır.

Değinilmesi gereken önemli bir kaynak da Murat Erdoğan'ın “Suriyeliler Barometresi, 2019” çalışmasıdır. Erdoğan bu çalışmasında Türkiye'de yaşayan Suriyeli sığınmacı sayısının her geçen gün artması yerel halkı "güvenlik sorunları, maliyetler, hizmetlerin aksaması, işini kaybetme, kimlik kaybı ve kontrol edilemezlik" vb. endişelere ittiği sonucuna ulaşmıştır. İlk etapta yerel halk Suriyeli sığınmacılarla iyi ilişkiler kurulabilmiştir, çünkü bu dönemde ev sahibi halk, "Ensar-Muhacir" anlayışıyla, kültürel benzerliklerle göçmenlere çoğunlukla yardımcı olmuş, (geçici kalacakları düşüncesiyle onları kabullenmiştir). Fakat daha sonraki süreçte Suriyelilerin sayısının artması, bu sürecin uzaması ve kalıcı olduklarına dair işaretlerin belirmesiyle bu durum tersine dönmüş, "bilinçli bir ötekileştirme" yaşanmış, sosyal mesafe artmıştır. Suriyeli sığınmacılar ise kendi içlerinde "yeni bir Suriyeli kimliği ve bir dayanışma ağı” oluşturmaya başlamışlar, kendilerine ait yeni bir toplumsal yapı kurmaya yönelmişlerdir. Bu da doğal olarak Suriyeli sığınmacıların yerel halka olan ihtiyaç seviyesini azaltmıştır. Bu durum ise yerel halkın endişelerinin artmasındaki nedenlerden birini teşkil etmiştir. ${ }^{10}$ Buradan yola çıkarak yaşanan bu insani karşılaşmanın birçok açıdan kodlarının ortaya konulması gerektiği iddia edilebilir. Böylelikle iki toplumun da her alanda (bu çalışmada yükseköğretim alanı) birlikte yaşamasına yönelik güçlü ve zayıf yanlarının ortaya konularak geleceğe yönelik yeni stratejiler geliştirilebilecektir.

\section{Metodoloji}

$\mathrm{Bu}$ çalışmada nitel araştırma yöntemleri kullanılmıştır. Harran Üniversitesi’nde çeşitli bölümlerde öğrenim gören Suriyeli öğrencilerden

\footnotetext{
${ }^{10}$ M. Murat Erdoğan, Suriyeliler Barometresi 2019, Suriyelilerle Uyum İçinde Yaşamın Çerçevesi (Ankara: Orion Kitabevi, 2020), 202-203.
} 


\section{Hakan GÜLERCE ve Rukiye ÇORLU}

oluşan ve her birinde altı kişilik katılımcı olmak kaydıyla odak grup görüşmesi yapılmıştır. Nitel araştırma insanların davranışlarını içerisinde bulundukları ortamların şartları içerisinde ve çok yönlü olarak anlamaya imkân verir. ${ }^{11}$ Creswell'e göre odak gruplarla gerçekleştirilen mülakatlar, görüşülenler arasındaki etkileşimin olası en iyi bilgiyi sağladığı görüşmelerdir. Bunun yanında mülakat yapılan bireylerin birbirine benzer ve işbirliği içerisinde olması, bilgi toplamak için zamanın sınırlı ve bireylerle birebir bilgi ediniminin şüpheli olduğu durumlarda avantajlara sahiptir. ${ }^{12}$ Öğrencilerle 2019 yılı Ekim ve Kasım ayları içerisinde iki odak grup görüşmesi gerçekleştirilmiştir. Bu görüşmelerin her birisi yaklaşık 60-70 dakika sürmüştür. Öğrencilerin de onayı alınarak görüşmeler ses

Üsküdar University Journal of Social Sciences, 2021; issue: 12 , 71-106 kayıt cihazıyla kayıt altına alınmıştır. Daha sonra deşifreleri yapılarak içerik analizi yapılmıştır. Çalışmada kullanılan diğer bir teknik ise gözlemdir. Gözlem tekniğinde önemli hususlardan birisi araştırmacıların gözlenenin ortamında bulunması ve yaşantısı üzerine doğrudan gözlem yapabilmesidir. ${ }^{13} \mathrm{Bu}$ çalışmayı yapan araştırmacıların üniversite içerisinde öğrenci ve akademisyen olması onlara gözlem yapma imkânı da sağlamıştır. Böylelikle odak grup görüşmelerinde elde edilen veriler gözlemlerle de desteklenerek daha zengin bir analiz imkânı sağlamıştır.

\section{Çalışmanın Sınırlııkları}

Çalışma sadece 12 kişiden oluşan Suriyeli sığınmacı öğrencilerle sınırlı tutulmuştur. Bu öğrenciler Türkiye'nin Şanlıurfa ilinde bulunan Harran Üniversitesi'nde çeşitli bölümlerde halen öğrenim görmektedirler. Dolayısıyla bu çalışmanın sonuçları Türkiye’deki bütün sı̆̆ınmacı

\footnotetext{
${ }^{11}$ Ali Yıldırım ve Hasan Şimşek, Sosyal Bilimlerde Nitel Araştırma Yöntemleri (Ankara: Seçkin Yayıncılık, 2017), 37.

${ }^{12}$ John W. Creswell, Nitel Araştırma Yöntemleri: Beş Yaklaşıma Göre Nitel Araştırma ve Araştırma Deseni (Ankara, 2014), 164.

${ }^{13}$ Suat Cebeci, Bilimsel Araştırma ve Yazma Teknikleri (İstanbul, 2002), 109.
} 


\section{Yükseköğretimdeki Suriyeli Sığınmacı Öğrenciler: Uyum ve Çatışma Alanları}

öğrencileri temsil etme iddiasında değildir. Ancak çalışma, bu haliyle, sığınmacı öğrencilerin neler deneyimledikleri konusunda belli başlı fikirler ortaya koyabilir. Her ne kadar çalışmada sadece Suriyeli öğrenciler tarafından bir bakış açısı ortaya konulmuş olsa da yapılan gözlemlerde bu durumun karşılıklı olduğu ifade edilebilir. Sığınmacıların sosyal dâhil edilmesi ve karşılıklı uyum konusu çok geniş olduğundan bu çalışmada sadece kabullenme, belirsizlik, toplumsal etkileşim, etiketleme ve ötekileştirme kavramları üzerinden elde edilen veriler ve gözlemler ışığında bir değerlendirme yapılmıştır.

\section{Kabullenme}

Yerel ve sığınmacı insanların yaşadıkları insani karşılaşma yaşanan göç sürecinin olmazsa olmazlarından birisidir. Bu karşılaşma birçok uyum ve çatışma alanlarını da beraberinde getirebilmektedir. Zaman zaman insanlar, uyum ve birlikte yaşama kültürünü geliştirerek kaynaşma sağlayabilirken zaman zaman çatışmalar yaşayabilmektedirler. Karşılıklı sorumlulukları beraberinde getiren uyumu etkileyen önemli faktörlerden birisi de toplumsal kabuldür. Bu çalışmada Bauman'ın kabullenme kavramı toplumsal kabul çerçevesinde değerlendirilecektir.

Bauman bu karşılaşma ve birlikte yaşama sürecini ele aldığı bir eserinde atık kültüründen bahseder. Ona göre atık insanlar, çeşitli gerekçelerle toplumdan dışlanan insanlardır. Bu gerekçeler ne kadar farklı olursa olsun atık insanların sahip oldukları duygu aynıdır. Hayatta kalabilmek için amansız bir mücadeleye giren bu insanlar, sosyal konumlarını, özgüvenlerini, özsaygılarını kaybetmekte, içinde bulundukları durum üzerine derin düşünmek için bir neden bulamamaktadırlar. Toplum tarafından kabul görmeme duygusu yaşamaları, kızgınlık, öfke ve nefret duymaları anlaşılır olmakla birlikte bunlara karşı bir direnme içerisine de girmemektedirler. Çünkü atık insanlar bunların boşuna olduğunu bizzat deneyerek öğrenmiş, kendilerini diğerlerinden aşağıda görerek tüm bu 


\section{Hakan GÜLERCE ve Rukiye ÇORLU}

durumu kabul etmişlerdir..$^{14}$ Artık yabancı ne vardığı ülkeye ne de kendi ülkesine tam anlamıyla ait değildir. Nitekim Bauman bu durumu, Prag'daki bir tören sırasında tecrübe etmiştir. Charles Üniversitesi'nde gerçekleşen bir törende fahri doktora ödülü alan kişinin ulusal marşını çalma ritüeli, Bauman için söz konusu olmamıştır. Bauman'ın isteğiyle ne Polonya ulusal marşı ne de İngiltere ulusal marşı çalınmamış, Avrupa Birliği marşı çalınmıştır. ${ }^{15}$ Bauman, kendisinin Leh kimliğini kazanması gerektiğini fakat bunun hiçbir zaman sonlanmayacağını fark ettiğini ifade etmektedir. $\mathrm{Bu}$ durumu "Benim Leh kimliğimi kazanmam ve bu kimliğe hakkım olduğunu "kanıtlamam" gerekti; ancak kısa bir süre sonra bu cefanın hiçbir zaman bitmeyeceğini ve ölümüme -hatta daha sonrasına- kadar

Üsküdar University Journal of Social Sciences, 2021; issue: 12 , 71-106 sürdürülmesi gerekeceğini fark ettim” şeklinde değerlendirmektedir. ${ }^{16}$ Bauman bu durumu "...bir kez nevzuhur olduğunuzda, yeni gelen olmaktan tam anlamıla kurtulabilir misiniz?" ${ }^{17}$ sorusuyla da vurgulamak ister. Dolayısıyla göç ile birlikte değişen ve dönüşen kimliklerin artık bir insanın bir ömür beraberinde taşıyacağı bir olgu haline geldiği söylenebilir.

Atık insanlar olarak sığınmacılar geldikleri toplumda ne asimile olabilirler ne de faydalı bir işlev görürler. Bulundukları yerden ne ileriye gidebilirler ne de geriye gidebilirler. Gidebilecekleri yer en fazla toplumun ücra köşeleridir. Kamplar yerel halktan uzakta bir yerdedir ki "sosyal çürümenin zehirli kokusu” onlara ulaşmasın. Kamp alanı içinde unutulan mülteciler kamp alanı dışında "baş belası ve dert kaynağı” olarak görülür. Mültecinin kimliği duvarlarla, dikenli tellerle, kapılarla ve bekçilerle yok edilir. Mültecilerin tüm farklılıkları, bireysellikleri, kişisel özellikleri

${ }^{14}$ Zygmunt Bauman, Iskarta Hayatlar \& Modernite ve Safraları, çev. Osman Yener, (İstanbul: Can Yayınları, 2018), 54.

${ }^{15}$ Zygmunt Bauman, Kimlik, çev. Mesut Hazır (Ankara: Heretik, 2017), 17-18.

${ }^{16}$ Zygmunt Bauman ve Stanislaw Obirek, Dünyaya ve Kendimize Dair, çev. Burcu Halaç (İstanbul: Ayrıntı Yayınları, 2018), 150.

${ }^{17}$ Bauman, Kimlik, 17. 


\section{Yükseköğretimdeki Suriyeli Sığınmacı Öğrenciler: Uyum ve Çatışma Alanları}

“aynı çöplüğe” atılarak ortadan kaldırılır. Böylece mültecinin, toplumun "meşru ve saygın" bir bireyi olma ümidi de azalır. ${ }^{18}$ Aslında bu durum sadece kamp alanlarıyla, gettolarla sınırlı değildir. Bu alanların dışında da mülteciler "meşru ve saygın" kabul edilmezler. Toplumun içinde olsalar da hiçbir zaman toplumun bizatihi içinde yer almazlar. $\mathrm{O}$ toplumdan farklı olduklarının, onlar gibi olmadıklarının farkındadırlar. Bu bağlamda odak grup görüşmesine katılan bazı sığınmacı katılımcılar kabullenme bağlamında sorulan bir soruya şöyle cevap vermişlerdir:

"Babam bizi 'İki ay kalacağiz geri döneceğiz' diyerek ikna etmişti. Hep döneceğim hayali vardı. Ama sonra dönmeyeceğimizi fark ettik. Göç ettikten sonra bambaşka hayallerim oldu. Kabul ettim artık nerede olduğumu, nasıl yaşam gerektiğini. Önyargı arkadaşlardan değil de çevrede oldu. Pek takılmadiğım için aklıma gelmiyor. Kafama çok takmiyorum. Her zaman olacak bir şey. Her birine takilirsam zaten başım çok ağrır." (K1, Kadın, 22)

"Abime vatandaşlık almak için valiliğe gitmiştik. Oradaki bir kadın -Türkler Suriye'ye girmişti- "Siz burada geziyorsunuz vatandaşlı alyorsunuz. Bizim çocuklarımız Suriyédeler. Siz ne yapıyorsunuz burada?" dedi. Ben baktım sadece, ne diyeceğimizi bilemedik." (K2, Erkek, 19)

"Bazı arkadaşlarımız "Bizim ordumuz orada savaşıyor. Sen burada hemşirelik okuyorsun. Valla bravo sana, lüks" falan demişti. Ben de "Ne savaşından bahsediyorsun. Ben asker olarak gidebilir miyim sence? 15 yaşındaki bir çocuk savaşabilir mi?" dedim. Aslinda ben bu gibi konularda tartışmıyorum. Çünkü çözümsüz." (K9, Erkek, 19)

Görüldüğü gibi öğrenciler akranlarından ziyade onları tanımayan çevrelerindeki diğer insanlar tarafından ötekileştirildiklerini ve bu bağlamda toplumsal kabulun gerçekleşmediğini ifade etmektedirler. Aynı zamanda yerel halkın kendi yaşamlarını sığınmacıların yaşamlarıyla

\footnotetext{
${ }^{18}$ Bauman, Iskarta Hayatlar \& Modernite ve Safraları, 94-95.
} 


\section{Hakan GÜLERCE ve Rukiye ÇORLU}

kıyaslamakta olduğu ortaya çıkmıştır. Böylelikle sığınmacı öğrenciler yerel halk tarafından imtiyazlı görülmektedirler. Bu durum da sığınmacılara karşı bir çeşit öfke, rekabet veya toplumsal red sorununu ortaya çıkarmaktadır.

Erdoğan'inyaptığıçalışmada Türk toplumunun (yerelhalkın) toplumsal kabul düzeyi zamanla yavaşlamaktayken, Suriyeli halkın (sığınmacıların) Türkiye'ye uyumu normalleşme seviyesine yükselmekte olduğu sonucuna ulaşılmıştır. Fakat bu azalmaya rağmen Türk toplumunun Suriyeli sığınmacıları kabul düzeyi yüksek bir düzeyde devam etmekte, dayanışma ve yardımlaşma örnekleri hâlâ sergilenmektedir. ${ }^{19}$ Bununla birlikte ögrenciler kendilerine gelen olumsuz ve bilinçsiz (doğru bilinen yanlışlar) eleştirileri bir şekilde bertaraf etmenin stratejilerini de geliştirmektedirler. Her ne kadar daha çocuk yaştayken yedi günlüğüne evden çıan bugünün

Üsküdar University Journal of Social Sciences, 2021; issue: 12 , 71-106 üniversite öğrencisi sığınmacılar yedi yıldan fazladır geri dönememişlerse de bir şekilde göç ettikleri yeni yerde uyum içerisinde yaşamanın yollarını bulmaya çalıştıkları iddia edilebilir. Bütün bunlarla birlikte toplumsal uyumun önündeki engellerden ve sığınmacıların gelecek hayallerinin önündeki bariyerlerden belki de en büyügü olan belirsizliğin de devam ettiği gözlemlenmektedir.

\section{Belirsizlik}

Göçün beraberinde getirdiği sıkıntılardan birisi belirsizliktir. $\mathrm{Bu}$ durum belki de kişinin sosyal ve psikolojik açıdan hayata tutunmasının önündeki en önemli engellerden birisidir. Zorunlu olarak yerinden, yurdundan edilen bir kimse yaşadığı birçok sıkıntının yanında bir de belirsizlikle hiç bitmeyen bir mücadelenin içerisinde bulur kendisini. Artık ötekileştirmenin vücut bulmuş hali olan sığınmacılar, kimsesiz topraklar dışında her yerde yersiz yurtsuzdurlar. ${ }^{20} \mathrm{Bu}$ durum diğer bir ifadeyle "Her yerde tamamen ya da kısmen 'yersiz yurtsuz' olmak ve tam olarak hiçbir

\footnotetext{
${ }^{19}$ Erdoğan, Suriyeliler Barometresi 2019, Suriyelilerle Uyum İçinde Yaşamın Çerçevesi, 200-202.

${ }^{20}$ Bauman, Iskarta Hayatlar \& Modernite ve Safraları, 97.
} 


\section{Yükseköğretimdeki Suriyeli Sığınmacı Öğrenciler: Uyum ve Çatışma Alanları}

yerde olmamak" şeklinde büyük bir belirsizliğin ifadesidir. ${ }^{21}$ Bauman bu duruma "Bir kez mülteci olan, sonsuza dek mültecidir. Kaybettiği (ya da artık mevcut olmayan) yuvasına giden yollar kesilmiştir, yaşadığı araftan çıkan bütün yollar cehenneme gider.” şeklinde veciz ifadeleriyle işaret eder. ${ }^{22}$ Kendi ülkelerinden adım atar atmaz devletsizdirler. Tâbi olacak, hesap verecek, kendilerini koruyacak, kendilerini savunacak hukuki bir devlet, bir makam yoktur. Michel Agier' in belirttiği gibi "kanun dışındadırlar”. Ama bu, herhangi bir ülkenin kanunu dışında olmak değil, "kanun" mefhumunun dışında olmaktır. Tahmin edilemeyen bir "eşikte sürünme” durumudur. Mülteciler, istikameti belirsiz ve hiçbir zaman tamamlanmayacak bir yolculuğa çıkmışlardır. Gittikleri her yere yanlarında geçiciliği, belirsizliği ve eğretiliği taşırlar. ${ }^{23}$ Belirsizlik konusunda bazı sığınmacı öğrenciler aşağıdaki ifadeleri dile getirmişlerdir:

"Ben çok düşünmüyorum. Bugün bir sinavlm var bir tek ona çalışıorum. Geleceği tam düşünmüyorum. "Acaba o günü yaşayabilir miyim?” diyorum. Bir şey düşünüyorsun olmuyor. Bu çok zor. Bu yüzden artık düşünmüyorum." (K4, Erkek, 23)

"Vatandaşlik almadan önce düşünüyordum, ne olacak? diye. Vatandaşlik aldiktan sonra rahatladım. Ne olursa olsun beni Suriye'ye gönderemezler. Artık geleceğimi düşünebilirim. Ama tabi müphemlik var. Ben ne olacağım? Bilmiyorum. Okuldan mezun olacak mıyım? Türkiye'den mi gideceğim? Yeniden Suriye'ye mi gideceğim?" (K2, Erkek, 19)

Katılımcıların ifadelerinden anlaşılacağı gibi sığınmacı̈ŏgrenciler her ne kadar gelecek konusunda bazı düşüncelere sahip olsalar da yine de büyük bir belirsizliğin hâkim olduğu ortadadır. Bazı öğrencilerin bu belirsizlik ve

\footnotetext{
${ }^{21}$ Bauman, Kimlik, 22.

${ }^{22}$ Bauman, Iskarta Hayatlar \& Modernite ve Safraları, 96.

${ }^{23}$ Bauman, Michel Agier, Aux bords du monde, les réfugiés (Paris: Flammarion, 2002), 92.
}

Üsküdar

Üniversitesi

Sosyal Bilimler

Dergisi, 2021;

sayl: 12 ,

$71-106$ 


\section{Hakan GÜLERCE ve Rukiye ÇORLU}

gelecek hakkında sorulara sadece sessiz kalmaları da gerçekten anlamlıdır. Hatta Arapça bir deyim olan "ne yerdeyim ne semada" ifadesini sık sık kullandıkları gözlemlenmiştir. Yine Bauman’a göre sığınmacıların yaşamış olduğu bu yersiz yurtsuzluk durumu özgüvenin kaybolması gibi duygulara yol açabilmektedir. Bir ihtimal bu durumla karşılaşmayan kişilerde ise karşılaşma endişesi oluşturmaktadır. Dolayısıyla bu duygular ve hisler bu kişilerin içinde bulundukları topluma aidiyet hissetmelerinin önünde bir engel oluşturmaktadır. ${ }^{24}$ Richard Sennett' in de ifade ettiği gibi "Yabancı olmak, memleketi dışında yaşarken bir türlü iç rahatllğına kavuşamamak demektir." ${ }^{25}$ Katılımcı bazı öğrencilerin aşağıdaki ifadeleri bu duruma örneklik teşkil etmektedir:

Üsküdar

University

Journal of Social

Sciences, 2021; issue: 12 , 71-106

"Her bir olay olunca aklımıza ilk gelen 'İnşallah Suriyeli değildir' oluyor. Ben tıp düşünüyordum. Çalışmam, derslerim hep iyiydi. Hayallerime ilk başta ulaştım, burada tıbbı kazandım, ama gitmedim. Yaşama koşulları değişti, ben burada kalmayacağım ki. Türkiyéde kalıp kalmayacağımı bilmiyorum." (K1, Kadın, 22)

"Suriyeli olarak Türk vatandaşlğın kazanmamak evet bir müphemlik oluşturuyor. Ben şimdi Türk vatandaşlğına dayanarak bir iş yapabilirim Türkiye'de ya da yurt dışında. Birçok düşüncem var, ticaret yapmak gibi. Mühendislikte değil farkh bir sektörde çalı̧̧mayı düşünüyorum. Çalı̧̧maya engel olan şeylerden biri Suriyeli olmak. Ne pasaportumuz var ne başka bir şey. Yani belirsizlik var geleceğimize dair." (K7, Erkek, 24)

"Bende durum vahim. Çünkü hemşire olduktan sonra KPSS var. O da ayrı bir yarışma, ayrı bir savaş. Atanıp atanamayacağı da belli değil. Türk vatandaşı olsam böyle. Türk vatandaşı olmayanlar için durum daha da kötü, daha da vahim. Çünkü yaşamak için çalışmak lazım, bir

\footnotetext{
${ }^{24}$ Bauman, Iskarta Hayatlar \& Modernite ve Safralari, 25-26.

${ }^{25}$ Richard Sennett, Yabancı: Sürgün Üzerine İki Deneme, çev. Tuncay Birkan (İstanbul: Metis Yayıncılık, 2017), 52.
} 


\section{Yükseköğretimdeki Suriyeli Sığınmacı Öğrenciler: Uyum ve Çatışma Alanları}

işyeri açmak lazım. Türkvatandaşı olmayanların Türkiye'de gelecekleri yok. Ama Türk vatandaşı olanlar için baya katkı sağlayacak." (K9, Erkek, 19)

Savaş ortamından daha güvenli bir yere kaçan, yakınlarından ve akrabalarından yaşanan ölümlerin acısını hâlâ taşıyan insanların yeni bir toplumda yeni bir hayata ayak uydurarak uyum sağlaması oldukça zordur. $\mathrm{Bu}$ zorlukların başında onların birçok konuda yaşadıkları belirsizlikler gelmektedir. ${ }^{26} \mathrm{Göç} \mathrm{süreciyle} \mathrm{birlikte} \mathrm{hayatlar} \mathrm{önemli} \mathrm{ölçüde} \mathrm{değişmektedir.}$ Göçmenler bir taraftan yeni hayatlarına uyum sağlayıp geleceklerini kurmaya çalışırken diğer taraftan yabancı veya öteki olmanın sıkıntılarıyla ve büyük bir belirsizlikle baş etmek zorunda kalırlar. Bütün bunların üzerine bir de toplumsal etkileşim ve iletişim kurma sorunları da eklenir.

\section{Toplumsal Etkileşim}

Yerinden edilenler ile yerel halkın karşılaşmasını zorunlu kılan göç, bir anlamda yeni sosyal ilişkilerin kurulması demektir. Fakat bu ilişkiler her zaman başarıyla kurulamayabilir. Buna neden olan en büyük etkenlerden biri kuşkusuz toplumsal etkileşimin yetersizliğidir. Ev sahibi halkın sığınmacılar hakkında sahip olduğu endişe, korku, belirsizlik vb. pek çok duygunun yansıması çoğunlukla göç eden kişilerle ilişki kurmaktan kaçınmak olmaktadır. Doğal olarak bu durum bir arada yaşama amacını da sekteye uğratmaktadır.

Bauman insan ilişkilerine "biz", "onlar” ve "yabancılar" üçlemesinden bakmaktadır. "Biz" ve "onlar" sadece iki ayrı insan grubunu tanımlamaz, karşıt tutumları da ("duygusal bağlanma ve antipati, güven ve kuşku, güvenirlik ve korku, işbirliği ve çekişme") içermektedir. "Biz" ait olunan grubu temsil eden, kişinin kendini güvende ve evinde hissettiği gruptur.

\footnotetext{
${ }^{26}$ Hakan Gülerce, “Göç ve Belirsizlik: Eşleri Kayıp Suriyeli Sığınmacı Kadınlar”, İnsan \& Toplum 10, sayı: 3 (2020): 218, https://doi.org/10.12658/V0001
} 


\section{Hakan GÜLERCE ve Rukiye ÇORLU}

"Onlar” kişinin ait olmayı istemediği gruptur. ${ }^{27}$ "Biz" ve "onlar” dişında ise "yabancılar" bulunmaktadır. Bu grup gizemli veya bilinmez bir grup değildir. Aksine "yabancılar" hakkında bir takım bilgiler mevcuttur. Defalarca görüş alanına dâhil olan bu grup, istenilsin veya istenilmesin içinde bulunulan çevrede yaşarlar. Dolayısıyla sürekli görülen ve duyulan insanlardır. Varlıkları göz ardı edilemez. Ama ne "biz" grubuna ne de "onlar" grubuna dâhil edilebilir. Ne dost ne de düşmandırlar. ${ }^{28}$ Bir anlamda arafta bulunan "yabancı"ların "biz" olamamasının en önemli nedenlerden biri sahip olunan önyargılardır. Onlara dair sahip olunan yanlış düşünceler, pek çok asılsız söylem, korku, endişe, öngörülememe vb. pek çok argüman iletişimsizliği daha da körüklemektedir. Bu konuda görüşmeye katılan bazı sı̆̆ınmacı öğrencilerin ifadeleri şu şekildedir:

Üsküdar

University

Journal of Social

Sciences, 2021; issue: 12 , 71-106

"Yerel halkla ilişki kurmaktan çekiniyorum. Çünkü Suriyelilere yönelik yanlış düşüncelere sahipler. Bundan dolayı çekiniyorum. Buradaki insanlar biraz kızginlar. Yanlış bir şey yaptığında, kelime kullandığında hemen bağırıyorlar, tepki veriyorlar. Türklerle iletişim kurduğumda daha çok dikkat ediyorum." (K6, Erkek, 20)

"TÖMER'de okurken ögrretmenler gününde hocamız için küçük bir parti yapmıştık. Bize "Ülkenizde savaş var nasil parti yapıyorsunuz? Türkiye'de bir savaş olsaydı biz başka bir yere gitmezdik. Ülkemizden çımazdık" dediler." (K5, Kadın, 20)

"Ben apartmanda merdivenden çıkarken komşulara selam veriyordum. Ama onlar Suriyeli olduğum için cevap vermiyorlard. Bir sene sonra ben o apartmandan taşınmak istedim. Komşularımız bizi ağlayarak uğurladı, öyle vedalaştı. "Buradan gitmeyin, sizden daha iyi insanlar görmedik, kalı" dediler. Bir sene geçtikten sonra o defterin kapanması biraz zor. Onlar önyargllara dayanarak böyle davranmışlardı. Bizim

${ }^{27}$ Zygmunt Bauman, Sosyolojik Düşünmek, çev. Abdullah Yılmaz (İstanbul: Ayrıntı Yayınları, 2015), 51.

${ }^{28}$ A.g.e., 66. 


\section{Yükseköğretimdeki Suriyeli Sığınmacı Öğrenciler: Uyum ve Çatışma Alanları}

iyi olduğumuzu, dürüst olduğumuzu bilselerdi öyle davranmazlardı. Geçen sene kimya hocası ders anlatırken "Sizden kimin el yazısı güzel? Tahtaya çısıı" dedi. Ben el kaldırdım. "Sen nerelisin?" diye sordu. "Suriyelim" dedim. "Sen önce Latince alfabeyi çöz, ondan sonra gel" dedi. Sinıfin içinde beni utandırd. Ondan sonra o tip insanlarla görüşmedim." (K7, Erkek, 24)

"Bizlere karşı bir önyargı var. "Suriyeliler şuraya gidiyorlar, her şeyi yapıyorlar. Hiç umurlarında değil” gibi konuşuyorlar." (K8, Kadın, 23)

Yerel halkın sahip olduğu bu duygu ve düşünceler zaman zaman hınca, öfkeye, nefrete dönüşebilmektedir. Göçmenlerin normal yaşam şekillerinden uzaklaşması istenmektedir. Onların gülmesi, arkadaşlarıyla, akrabalarıla bir araya gelmesi, hatta oturmaları, sessizlikleri, giyim kuşamları, yemekleri bile rahatsız edici olabilmektedir. Bunlarla birlikte yerel halk, doğruları ve onların kim olduğunu öğrenmekten, göçmenlerle iletişim kurmaktan, onları tanımaktan olabildiğince kaçınmaktadır. Bauman böylesi bir durumda verilen ilk tepkinin, onları geldikleri yere geri göndermek olduğunu ifade etmiştir. Ona göre böyle bir tepki ile belirsizlik kaybolur ve netlik yeniden kazanılır. Göçe zorlamak, hayatlarını dayanılmaz kılarak bırakıp gitmelerini sağlamak veya bunlardan daha hafif kalacak bir diğer çözüm de ayrılmaktır. Fiziksel ayrılma; kamp alanları, gettolar vb. duvarlarla ayrılmış, yasal engellerle kuşatılmıştır. ${ }^{29}$ Bauman'ın Phillippe Robert'ten alıntıladığı gibi bu alanlar yerel halk ile yeni gelenler arasında aşılmaz bir duvar inşa etmekte, toplumsal açıdan değersizleşmiş, yerel halkla iletişimi koparılmış mekânlara dönüşmüştür. Göçmenler için burası kendilerini evde hissettikleri, düşmanca bakışlardan kurtuldukları tek yerdir. Buranın dışında ise yabancıdırlar. ${ }^{30}$ Richard Sennett bir

\footnotetext{
${ }^{29}$ A.g.e., 73 .

${ }^{30}$ Bauman, Iskarta Hayatlar \& Modernite ve Safraları, 100; Philippe Robert vd., "Une généalogie de l'insécurité contemporaine: Entretien avec Philippe Robert", Esprit, sayı: 290 (12) (2002): 35-58.
}

Üsküdar Üniversitesi Sosyal Bilimler Dergisi, 2021;

sayl: 12 , 71-106 


\section{Hakan GÜLERCE ve Rukiye ÇORLU}

çalışmasında yerinden-edilen Yahudilerin yeni mekânlarında -gettooluşturduğu yeni toplumsal yapıyı gözler önüne sermektedir. Gettolar, Venedik toplumundan dışlanan Yahudilerin ötekiliklerini arttırmıştır. ${ }^{31}$ Getto alanının içi onlar için kendi varlıklarını ve kimliklerini korudukları yerken, getto alanının dışı dış dünya, risk, tehlike, kimlik kaybı tehdidi olmaktadır. Sennett bu durumu "yer ile bedenin birbirine bağlantısı" olarak değerlendirmiştir. Zira böyle bir düzlemde kimlik, artık mekânsal bir deneyime dönüşmüştür. ${ }^{32}$ Günümüzde böylesi bir yerinden etme ya da duvarlarla örülmüş fiziksel bir ayrılık tam anlamıla söz konusu değildir. Fakat görüşme yapılan sığınmacı öğrencilerin belirli ortamlarda kendilerini daha rahat hissetmeleri, bu ortamlardaki sosyal ilişkilerinin daha fazla olması kısmi bir fiziksel ayrılığın olduğuna da işaret etmektedir.

Üsküdar University Journal of Social Sciences, 2021; issue: 12 , 71-106

Bu konuda bazı sığınmacı öğrencilerin ifadeleri şu şekildedir:

"Ben şansliydım. Benim oturduğum mahallede Suriyelileri seviyorlardı. Ben geldim tanıştırdılar beni. Bazı Arapça konuşanlar vardı. Caminin hocası çok iyi Arapça konuşuyordu. Türkçe öğretmeye çalışıordu. Ondan sonra dükkânlarda gel otur, Türkçe ögren diyorlardi. Derse giren arkadaşımla çekinmiyorum, konuşuyorum." (K2, Erkek, 19)

"Bizlere bazı yerlerde çokfazla değer vermiyorlar. Suriyeli olduğum için başka bir bakışla bakıyorlar. Bazı yerlerde değer veriliyor. Her yerde aynı değil. Mesela okulda bana değer veriyorlar ama çevremde çok fazla vermiyorlar. Suriyeli olduğum için başka bir bakışla bakıyorlar. Bizi tanımış olsalardı sıkıntı görmezdik." (K1, Kadın, 22)

"Memurların hepsiyle değil bazılarıla sıkıntı oluyor. Mesela bölümümüzün sekreteri bize çok yardım ediyor. Mesela ben bir dersin vizesine girmemiştim. Beni aradılar. "Mazeret için sağlık raporu getir" dedi. Bize çok yardım ediyor. Benim hocamla da konuşmuştu." (K5, Kadın, 20)

\footnotetext{
${ }^{31}$ Sennett, Yabanci, 13.

${ }^{32}$ A.g.e., 14-15.
} 


\section{Yükseköğretimdeki Suriyeli Sığınmacı Öğrenciler: \\ Uyum ve Çatışma Alanları}

"Illk tanışma anlarında tabi ki önyargılar olmuştu, ama ondan sonra yaşamadim." (K9, Erkek, 19)

Görüşme yapılan öğrencilerin aslında uyuma istekli ve dâhil edilme sürecinden oldukça memnun oldukları görülmektedir. Yerel halk ile sığınmacıları birbirinden uzaklaştıran, iletişımi koparan asıl ayrılık ise, manevi ayrılıktır. Bauman'a göre manevi ayrılma, toprak ayrımının yapılamadığı, sınır konulamadığı noktada ortaya çıkmaktadır. Bu ayrımda ilişkiler iş ilişkilerine indirgenerek manevi bir yakınlaşmaya engel olunmaya çalışılmaktadır. Aslında böyle bir ayrılma kalın duvarların oluşturduğu ayrımdan daha tehlikelidir. ${ }^{33}$ Böylesi bir durumda iletişim zorunlu ve kaçınılmaz bir iletişime evrilmekte, gerçek iletişim ortadan kaybolmaktadır. Bauman bu durumu "gerçek diyalog" ve "sahte diyalog" olarak ifade etmektedir. Gerçek bir diyalog kendinden farklı görüşleri olan hatta nefret edilebilecek görüşleri olan kişilerle konuşabilmektir. ${ }^{34}$ Gerçek bir diyaloğa girildiğinde mağlup olmak, yanlış bir düşünceye sahip olunduğunu anlamak, karşı tarafın haklı olduğunu kabul etmek peşinen kabul edilmesi gereken noktalardır. ${ }^{35}$ İşte bu riskler insanları iletişimden uzaklaştıran, kişinin hayatını zorlaştıran faktörlerdir. Manevi ayrılığın tecrübe edilişini bir katılımcı öğrencinin şu ifadelerinde görmek mümkündür:

"Ben sıkıntı yaşamamak için öncesinde öğreniyorum. Bazı memurların bakışları rahatsız ediyor. Sanki iğrençmişiz gibi bir bakıyorlar. İnanın çoktan beri öğrenci belgesi almam gerekiyordu, ama gitmiyorum. Korktuğum için değil sadece görmek istemiyorum. İletişim kurmaya hep ben başlyyorum. Mesela selam vermek için kimseyi beklemiyorum. Beklesem de zaten belki hiç benimle konuşmak istemiyor. Öyle bir durum var yani. Ben başlyyorum ilk. Her bir olay olunca aklimiza

\footnotetext{
${ }^{33}$ Bauman, Sosyolojik Düşünmek, 74.

${ }^{34}$ Bauman ve Obirek, Dünyaya ve Kendimize Dair, 159.

${ }^{35}$ A.g.e., 170.
} 


\section{Hakan GÜLERCE ve Rukiye ÇORLU}

ilk gelen "İnşallah Suriyeli değildir" oluyor. Ben sinffta zaten tek Suriyeliyim ama ben kimseden yardım almadan çalısıyorum." (K1, Kadın, 22)

Görüldügü gibi günümüzde yerinden etme ya da fiziksel bir ayrılıktan ziyade manevi ayrılık derin bir şekilde yaşanmaktadır. Nitekim yerel halk ile sığınmacılar sokakta, markette, otobüste, işyerinde vb. pek çok yerde karşılaşmaktadır. Fakat bu karşılaşma sığınmacıların göründüğü, fark edildiği anlamına gelmemektedir. Onlara karşı tutum tesadüfen ve isteksiz karşılaşmalar, en aza indirgenmiş ilişkiler olarak kalmaktadır. Erdoğan'ın çalışmasında da benzer bir sonuca ulaşılmıştır. Nitekim Türk toplumunun Suriyeli sığınmacılara karşı "çok güçlü ("uzak") bir sosyal mesafe" söz

Üsküdar University Journal of Social Sciences, 2021; issue: 12 , 71-106 konusudur. Bunun tam aksine Suriyeli sığınmacıların Türk toplumuna karşı sosyal mesafesi ise son derece olumlu olarak saptanmıştır. Buna benzer sonuçlar "kültürel benzerlik" noktasında da ortaya çıkmaktadır. Türk toplumu Suriyeli sığınmacılar ile kültürel benzerliğe sahip olmadıklarını düşünenlerin oranı gittikçe artmaktadır. Aynı şekilde Suriyeliler açısından durum tam tersidir. ${ }^{36}$ Suriyeli sığınmacılar bugün gettolarda yaşamasalar da yerel halkın duygu ve düşünceleriyle, onları tanımadan, bilmeden, görülmeyen duvarlar, gettolar inşa edilmektedir. Kuşkusuz yeterli sosyal ilişkilerin kurulamaması, kaçınılmaz olarak etiketlemeyi de beraberinde getirmektedir.

\section{Etiketleme}

Zorla yerlerinden edilen insanların yeni yerleştikleri yerlerde karşılaştıkları en önemli sorunlardan birisi de etiketleme olarak karşımıza çıkmaktadır. Etiketleme teorisi belirli bir sosyo-ekonomik sosyal sınıftan gelen insanların şiddetle anılmasının ve içinde bulunduğu sınıf ile etiketlenmesinin, aynısınıftan gelen diğer insanların da şiddet göstereceğini

\footnotetext{
${ }^{36}$ Erdoğan, Suriyeliler Barometresi 2019, Suriyelilerle Uyum İçinde Yaşamın Çerçevesi, 202-203.
} 


\section{Yükseköğretimdeki Suriyeli Sığınmacı Öğrenciler: Uyum ve Çatışma Alanları}

ifade eder. Bu durumda bir kişiye yapıştırılan etiketler, diğerlerinin bu kişi karşısındaki tutum ve davranışlarını şekillendirmektedir. ${ }^{37}$ Bauman bu sorunu yabancılık kavramı üzerinden ele alır. Sığınmacılar kapılarını çaldıkları insanlar için "yabancı", "yaban”, kaygıya neden olan, değerlerini, yaşam şekillerini değişikliğe uğratacak ya da yok edecek, haklarında öngörüde bulunulmayacak kişilerdir. Göçmenlerin üzerindeki belirsizlik onlara karşı korkunun ve kaygının en büyük nedenidir. ${ }^{38}$ Bauman'a göre göçün bir kriz olarak algılanmasının çeşitli nedenleri vardır. Televizyon haberleri, gazeteler, sosyal medya, politik demeçler vb. buna zemin hazırlamaktadır. Bunlar vasıtasıyla göç krizi, ilk olarak insanlarda korkulması gereken bir kötülüğün var olduğu izlenimi yaratan "ahlaki paniğe” yol açmaktadır. ${ }^{39} \mathrm{Bu}$ duruma görüşmeye katılan bazı sığınmacı öğrencilerin ifadeleri bir örneklik teşkil etmektedir:

"Geçenlerde Türkler yanımıza geldiler ve "Siz masum değilsiniz, siz kızlara bakıyordunuz" dediler. Ama aslında sokakta hiç kız yoktu. Başka bir Türk de bize "Onlara yaklaşmayın" dedi. Bize yardım etti. Insanlar bazı Suriyelileri iyi halde gördükleri için Suriyelilerin hepsini öyle zannediyorlar." (K2, Erkek, 19)

"Suriyeliler ile Türkler arasında problemler yaşanıyor. Yanlış düşüncelere sahipler, Suriyeliler Türklerin işlerini aldılar gibi. Daha az ücretle çalıştıkları için. Bence temel problem bu." (K6, Erkek, 20)

Yabancılar yerel halkın arasında yer aldığında şehir hayatının yıkımını sağlayan miksofobi, "baş edilemez ölçüde bilinmez, ehlileştirilemez, itici ve denetlenemez şeylerden duyulan korku” bir tepki yaratmaktadır. ${ }^{40}$

37 “Güvenlik Terimleri Sözlüğü”, içinde Etiketleme Teorisi (Ankara: T.C. İçişleri Bakanlığı Kamu Düzeni ve Güvenliği Müsteşarlığı, 2017), 208.

${ }^{38}$ Zygmunt Bauman, Kapımızdaki Yabancılar, çev. Emre Barca (İstanbul: Ayrıntı Yayınları, 2019), 14-15.

${ }^{39}$ A.g.e., 9-10.

${ }^{40}$ A.g.e., 15. 


\section{Hakan GÜLERCE ve Rukiye ÇORLU}

Yabancıların kamplara kapatılması, insan haklarından öte güvenlik önlemlerinin tartışılması, insan haklarının göz ardı edilmesi, suçlu olduğu düşünülen kişilere hiçbir tolerans gösterilmemesi gibi pek çok şey böyle bir duruma zemin hazırlamaktadır. Böylece üretilen yeni korkular güven duygusunun kaybolmasına, her şeyden şüphe duyulmasına neden olmaktadır. ${ }^{41}$ Göçmen bir kez etiketlendiğinde bir daha o etiketten kurtulması çok zor olmaktadır. Kendilerinin Suriyeli olduğunu vurgulu bir şekilde Türkiye'de hisseden gençler aşağıdaki düşüncelerini ifade etmektedirler:

"Bizim hakkımızda gerçeklerin söylenmesi lazım. Türkiyéde şöyle bir şey var; sadece küçük bir Suriyeli bir şey yaptığı zaman herkes

Üsküdar University Journal of Social Sciences, 2021; issue: 12 , 71-106 sanki onu yapmış gibi. Tek bir Suriyeli iyi bir şey yapınca kimse onu konuşmuyor. Ama kötü yapınca herkes onu konuşuyor. Kötü bir şeyler olunca "Suriyeliler şöyle yaptı" gibi görünüyor haberlerde." (K8, Kadın, 23)

"Bir olay olduğunda aslında tek bir Suriyeli değil diğerleri de gidiyor. Bir olay olunca aklımiza ilk gelen şey "İnşallah Suriyeli değildir" oluyor." (K1, Kadın, 22)

Görüldüğü gibi sığınmacı öğrenciler en ufak bir kavga veya gürültüde hemen kendilerine gelecek bir eleştiri veya suçlamadan endişelenmektedirler. Özellikle Suriyeli etiketiyle etiketlenen bir kişinin yaşadığı olumsuz bir durum bütün Suriyelilere mâl edilebilmektedir. Hakikatı aramada, doğru bilinen yanlışları ortaya çıkarmada ve farkındalık oluşturma konusunda toplumda önemli boyutlarda bir kayıtsızlık hali mevcuttur.

Göçün bir kriz olarak algılanmasına neden olan çabalar bir müddet öyle yoğun olmaktadır ki bu durum duyarsızlaşmayı, görmezden

\footnotetext{
${ }^{41}$ Bauman, Iskarta Hayatlar \& Modernite ve Safraları, 109-110.
} 


\section{Yükseköğretimdeki Suriyeli Sığınmacı Öğrenciler: \\ Uyum ve Çatışma Alanları}

gelmeyi ve normalleşmeyi de beraberinde getirmektedir. ${ }^{42}$ İzleyicilerin vicdan sızılarını bastıran bu tür bir kayıtsızlık hali, bireyleri ahlaki değerlendirmeden de muaf tutmaktadır. ${ }^{43}$ Daha önce de ifade edildiği gibi "biz" ve "onlar" grubu iki zit grubu işaret ederken, "yabancilar" grubu gri bir alanı temsil eder. Aslında "biz" ve "onlar” birbirlerine taban tabana zıt olsalar da varlıklarını devam ettirebilmek için birbirlerine ihtiyaç duymaktadır. Grubun kimliği ve dayanışması böyle sağlanmaktadır. Fakat bu durum "yabancılar” için geçerli değildir. Aslında “yabancılar”, diğer iki grubun sınırlarının geçirgenliğini, tehdit altında olduğunu ortaya koymaktadır. "...kaçkınlar, değerlerin yıkıcıları, birliğin düşmanları, dönekler” tarafından içeriden aşındırılan sınır, kendilerine benzemeyen ama öyle görünen "yabancılar" ın dışarıdan aşındırmasına neden olur. Böylece onlar, sınırın aslında geçirimsiz olduğunu gözler önüne sermişlerdir. Fakat bu durum onlara karşı nefret beslenilmesi ve geldikleri yere geri gönderilmesi için yeterli bir argümandır. Yabancılar, güvensizliği, tehlikeyi, kuşkuyu ortaya çıkarmaktadır. ${ }^{44}$ Kendilerine güven veren yaşama biçimlerine kafa tutmaktadırlar. Onların "soruları saldırı, tezleri bozgunculuk, karşılaştırmaları da küstahlık ve kindarlık” olarak algılanmaktadır. ${ }^{45}$ Hatta zaman zaman onların oturmaları, sessizlikleri bile rahatsız etmektedir. Geldikleri toplumun hayatını öğrenmeye çalışmak kendilerini taklit etmektir. Onlar gibi yaşayacak, onlar gibi giyinecek, onlar gibi çalışacak, onlar gibi eğlenecek, onlar gibi yürüyeceklerdir. ${ }^{46}$ Erdoğan'ın yaptığı çalışmada Türk halkının sahibi olduğu "endişeleri ve şikayetlerinin bir bölümünün eksik ve yanlış bilgilerden, bir bölümünün

\footnotetext{
${ }^{42}$ Bauman, Kapımızdaki Yabancilar, 10.

${ }^{43}$ A.g.e., 33.

${ }^{44}$ Bauman, Sosyolojik Düşünmek, 70.

${ }^{45}$ A.g.e., 71.

${ }^{46}$ A.g.e., 72.
}

Üsküdar

Üniversitesi

Sosyal Bilimler

Dergisi, 2021;

sayl: 12 ,

71-106 


\section{Hakan GÜLERCE ve Rukiye ÇORLU}

ise algılardan kaynaklandığını ortaya koymaktadır." ${ }^{47}$ Bütün bu önyargı ve etiketlemenin kaynağı aslında ötekileştirmenin altında yatmaktadır.

\section{Ötekileştirme}

Günümüzün büyük sosyal sorunlarından ve birlikte yaşama kültürünün önündeki engellerden birisi de insanları, inançlarından, düşüncelerinden, rrklarından, sınıflarından, mesleklerinden ve her türlü sosyal statülerinden dolayı ötekileştirmektir. Hilal Binti ötekileştirme üzerine yaptığı bir çalışmasında ötekileştirmenin beraberinde nesneleştirmeyi de getirdiğini ve bu durumun vahim sonuçları olacağını "öteki, berikinin bilincinde ve vicdanında nesneleştirildikten sonra damgalanır. Artık o ağaç gibi veya

Üsküdar University Journal of Social Sciences, 2021; issue: 12 , 71-106 taş gibi bir şeydir. O, iradesi dikkate alınmaksızın her tür muameleye layık görülür” şeklinde ifade eder. ${ }^{48}$ Öteki kavramına yapılan vurgu aslında “biz”'e ait olan yoğun vurgudan kaynaklanmaktadır. Aidiyet duygusuna yapılan aşırı vurgu diğer insanlarla kurulan ilişkilerde “öteki”leştirmeyi önemli bir araç haline getirmektedir. ${ }^{49}$ Elbette ötekinin oluşturulmasında "biz” önemli bir yere sahiptir, ancak göçmenler özelinde konu değerlendirildiğine birçok başka sebeplerin olduğu ortaya çıkmaktadır. Bauman'ın Franz Kafka'dan yaptığı alıntı, tek bir cümle ile ötekileştirmeyi özetlemektedir: "Her halükârda beş kişiyiz ve altı kişi olmak istemiyoruz."

Bauman ötekiliği "sskarta” kavramılla özdeşleştirir. Ona göre 1skarta hayatlar için kendi iradeleriyle yaşamlarını sürdürecek yerler yoktur. Onlar için "atık döküm alanları" oluşturulmalıdır. Buralar gettolar, hipergettolar

\footnotetext{
${ }^{47}$ Erdoğan, Suriyeliler Barometresi 2019, Suriyelilerle Uyum İçinde Yaşamın Çerçevesi, 204.

${ }^{48}$ Hilal Binti, "Ötekileştirme”, Avrasya Sosyal ve Ekonomi Araştırmaları Dergisi 4, sayı: 3 (1 Mart 2017): 4.

${ }^{49}$ Şevket Ökten, “Zorunlu Göç Zor(un)lu Kabul: Ceylanpınar Afgan Göçmenleri Üzerine Sosyolojik Bir Araştırma”, Harran Üniversitesi İlahiyat Fakültesi Dergisi 28, sayı: 28 (1 Aralık 2012): 178.

${ }^{50}$ Bauman, Iskarta Hayatlar \& Modernite ve Safraları, 21.
} 


\section{Yükseköğretimdeki Suriyeli Sığınmacı Öğrenciler: Uyum ve Çatışma Alanları}

ya da kamp alanlarıdır. Fakat yerel halkın sahip olduğu hınç ve öfke, yeni gelenlere karşı aşılmaz bir duvar oluşturmaktadır ki bu durum göçmenlerin yabancılaşmasını kolaylaştırmaktadır. ${ }^{51}$ Aslında önyargı, hınç ve öfkeyle örülmüş bu duvar gerçek bir duvardan daha etkilidir. Artık yabancıyı hatırlatan her şeye karşı; hareket etme biçimlerine, giyim kuşama, yemeklere vb. karşı hınç duyulmaya başlanmaktadır. ${ }^{52} \mathrm{Bu}$ da araya koyulacak mesafelerle kendisini göstermektedir. Örneğin yabancilarla araya set çekilmesine yarayan "kontrol noktaları, resepsiyon ve güvenlik görevlileri” ötekileştirmenin işaretleridir. İçeriye girmeyi isteyen kişi, oraya girmeye hakkı olduğunu ispatlamak zorundadır. ${ }^{53}$

Bauman zenofobi kavramına dikkat çeker. Zenofobi, kendilerinden farklı olan herkese karşı büyük bir nefret duymaya yatkın kişilerin, yabancı olan her şeye karşı gösterdikleri düşmanlıktır. Bununla birlikte fazlasıyla önyargıya sahip olan insanlar da tek tiplikten yana olup herhangi bir değişikliğe ya da değişik olan bir şeye katlanamazlar. ${ }^{54}$ İnsandışılaştırma, Bauman'ın ifadesiyle "onların meşru insan hakları sahipleri kategorisinden

Üsküdar Üniversitesi Sosyal Bilimler Dergisi, 2021;

sayl: 12 , $71-106$ dışlanması," göçmen meselesini çıkmaza sürüklemektedir; güvenlik tehdidi, suçlama ve cezalandırma, düşmanlık vb. (potansiyel tehdit olarak görmek).55 Diğer bir ifadeyle göçmenleri kurban haline getirmektedir (kurbanlaştırma). ${ }^{56}$ Odak grup görüşmelerine katılan bazı katılımcılar bu bağlamda aşağıdaki ifadelere yer vermişlerdir:

"Beni çok tanımıyorlar. Suriyeli olduğum çok belli olmuyor. Ama dışlanma özellikle kızlara çok fazla oluyor. Başörtüsünden dolayı

\footnotetext{
${ }^{51}$ A.g.e., 100.

52 Bauman, Sosyolojik Düşünmek, 74.

${ }^{53}$ A.g.e., 77.

${ }^{54}$ A.g.e., 59.

${ }^{55}$ Bauman, Kapımızdaki Yabancilar, 70.

${ }^{56}$ A.g.e., 90.
} 


\section{Hakan GÜLERCE ve Rukiye ÇORLU}

hemen belli oluyor Suriyeli olduğu. Suriyeli deyince insanlar sanki bir küfür gibi algiliyor. İnsan biraz rahatsız oluyor bundan." (K1, Kadın, 22)

"Bazi hocalar var Suriyelileri sevmiyorlar. Bazen ofise gidiyoruz "Toplantım var." diyor. Bir iki saat dişarıda birakıyor. Ondan sonra "Gel" diyor. Türkiyeli öğrenci giriyor. Bizi başından atıyor. Geçen yıl bir proje yapılmış. Katılanlar bin lira verilmiş. Suriyelilere, bizlere bir şey söylememişler sadece Türkleri almışlar. Arkadaşım anlatmıştı. Yazın da yine bir proje varmış üç gün süren. Herkes bin lira almış Suriyeli kimseye söylememişler." (K2, Erkek, 19)

Göçmenler/yabancılarla iletişim kurmamız, onlarla ilgili bilgi edinmekten kaçınmamız onlar hakkında gerçek bilgilerin aksine yanlış

Üsküdar University Journal of Social Sciences, 2021; issue: 12 , 71-106 düşüncelere, önyargılara neden olmaktadır. Richard Sennett bu durumu onlar hakkında kurulan "fantaziler" olarak ifade etmiştir. Fakat onlar hakkında bilgi sahibinin olmanın tek yolu olan bu fantaziler "farklılığı kavranması imkânsız bir ötekiliğe çevirir." ${ }^{77}$ Aynı durumu William Shakespeare de Venedik Taciri adlı oyununda yine Yahudiler üzerinden yabancılara karşı duyulan öfkeyi, kini, düşmanlığı sergilemiştir. Ana karakterlerden YahudiShylockkötü,çıkarcı,horgörülenolaraknitelenirken, bu niteleme onun sadece Yahudi olmasından kaynaklanmaktadır. Bunun farkında olan Shylock III. Perde / I. Sahne'de bu durumu şöyle dillendirir:

"Ben Yahudi'yim de ondan. Yahudinin gözü yok mu? Yahudi'nin elleri yok mu; organları, boy posu, duyuları, duyguları, heyecanı yok mu? Ayn yiyecekle beslenmiyor mu, ayn silahla yaralanmiyor mu, ayn hastaliğa yakalanmıyor mu, aynı yolla iyileşmiyor mu, aymı kışın ve yazın üşüyüp ısınmıyor mu? Farkı ne Hiristiyan insandan? Etimizi kesince bizim de kanımız akmaz mi? Gidiklanınca gülmez miyiz? Zehirlenirsek ölmez miyiz?"s8

\footnotetext{
${ }^{57}$ Sennett, Yabanci, 42.

${ }^{58}$ William Shakespeare, Venedik Taciri, çev. Bülent Bozkurt (İstanbul: Remzi Kitabevi, 2013), 75-76.
} 


\section{Yükseköğretimdeki Suriyeli Sığınmacı Öğrenciler: Uyum ve Çatışma Alanları}

Ötekileştirmeye başladığımızda aslında “diğer”lerinibirneviinsanlıktan çıkarmaktayız. Odak grup görüşmelerinden iki katılımcı aşağıdaki ifadelere yer vermiştir. Bu ifadelerden de aslında eğer bir grup öteki ilan edilmişse artık ona en insani durumlar bile çok görülebilmektedir.

"Ben başka bir şehre gitmek istersem Göç İdaresine gidip izin almam lazım. Ama bazen izin vermiyorlar. Bu şüphe değil mi? Bu hükümet tarafindan bize karşı bir şüphe. Ben kendimi hep yabancı olarak hissediyorum. Suriyeli olduğum için bana yabancı olarak bakıyorlar. Tanınma, değer verme yok." (K5, Kadın, 20)

"Mesela tenis oynamaya gittiğimde ben sadece Arapça konuşursam kendimi dışlanmış hissediyorum." (K6, Erkek, 20)

Öğrenciler açısından değerlendirildiğinde Suriye ve Yemen gibi savaş, ilhak ve ulusal felaketlerin yaşandığı ülkelerden gelen öğrencilere, 2014 ve 2015 'ten bu yana "özel öğrenci” sayılmaları ve özel durumları nedeniyle Türkiye, bazı ülke vatandaşlarını gerekli belgeleri sağlamaktan mazur görmektedir. ${ }^{59} \mathrm{Bu}$ durumun bazı teknik noktalardan uyumu kolaylaştırıcı etkisi olsa da insanların zihinlerindeki duvarların ve yaşanan uyum sorunlarının daha derinlerden geldiği ifade edilebilir. Örneğin bir ders esnasında bir sığınmacı öğrenci aşağıdaki bahsettiği olumsuz durumu yaşayabilmektedir:

"Geçtĭgimiz yıl Erasmus ofisi tarafindan verilen Avrupa'da öğrenime devam etme şansı için pasaporta ihtiyacımız vardı. Bizim Suriye'den ya da büyükelçilikten pasaport çıkarmamız çok zordu. Avrupa'da geçici kimlik gibi geçici pasaport veriliyor sığınmacılara. Bize de öyle bir pasaport verilmiş olsaydı bu fırsatı kaçırmazdım. Şimdi Avrupa'da öğrenim hayatına devam edebilirdim." (K7, Erkek, 24)

\footnotetext{
${ }^{59}$ Sanaa Talwasa, “Seeking a 'Better Life' in Turkey: Afghan Refugees' International Human Rights Condition in Turkey," Üsküdar Üniversitesi Sosyal Bilimler Dergisi, sayı: 11 (Kasım 2020): 261, http://doi.org/10.32739/uskudarsbd.6.11.76
} 


\section{Hakan GÜLERCE ve Rukiye ÇORLU}

"Elazığ depremi olduğunda ben Kizılay ile yemek dağıtmaya gittim. Bizim ekipten biri "Biz 2011'den beri size yardim ediyoruz. Siz de biraz yardım edin bari” dedi. Tartışmayı kestim, çıktım oradan. Benim çok zoruma giden bir olaydı. Yanlı̧ düşünceler dolaşıyor sosyal medyada, dışarıda, sokakta. Herkesten garip bakışlar aldik. Üniversiteye girmeden önce biraz değersiz hissediyorduk. Üniversiteye girdikten biraz daha değişti. Dostlarımız oldu. Gittiğimiz geldiğimiz arkadaşlarım var artık. Aileleriyle de tanışıyoruz." (K9, Erkek, 19)

Sığınmacı öğrenciler her nekadar ötekileştirmeye maruz kalsalar dayine de bir şekilde hayata tutunmaya ve önyargıları kırmaya çalışmaktadırlar. Almanya'daki göçmen öğrenciler üzerine yaptığı bir çalışmada F. Güzin Ağca-Varoğlu, öğrencilerin "sosyal ortamlarında karşılaştıkları önyargılarla

Üsküdar University Journal of Social Sciences, 2021; issue: 12 , 71-106 taktiksel olarak baş etme çabasına girme gereği duymaktadırlar” şeklinde ifade etmektedir. ${ }^{60} \mathrm{Bu}$ durumun bir benzerinin Suriyeli sığınmacılar açısından da yaşandığı gözlemlenmektedir. Eğer sosyal uyumun iki yönlü gerçekleştiğini düşünecek olursak bunun için her iki tarafin da desteğe ihtiyaçları olduğu bir gerçektir. İnsanların ve insanlığımızın omuzuna yüklenmiş sorumluluklarını yerine getirmek hepimizin borcu olmalıdır. Bunun için yapılacak çok şey var. Odak grup görüşmelerinde son olarak yapılması gerekenler üzerine bir oturum gerçekleştirildi. Böylelikle çalışmada ortaya konulan sosyal sorunların çözümüne yönelik çeşitli öneriler de geliştirilmiş oldu.

\section{Neler Yapılmalı?}

Yükseköğretimdeki sığınmacı öğrencilerin birçok uyum ve çatışma alanları ile karşı karşıya oldukları bir gerçektir. Bu aslında gayet insani bir durumdur. Önemli olan bu süreci nasıl yönetebileceğimizdir. İnsanoğlu bir kayıp nesile de odaklanabilir, kazanılmış bir nesile de. Bu bağlamda

${ }^{60}$ F. Güzin Ağca-Varoğlu, "Almanya'da Yüksek Nitelikli Göçmenlerin Gündelik Hayat Deneyimleri ve Baş Etme Süreçleri," Journal of Economy Culture and Society, sayı: 62 (25 Aralık 2020): 10-11, https://doi.org/10.26650/JECS.2019-0124 


\section{Yükseköğretimdeki Suriyeli Sığınmacı Öğrenciler: Uyum ve Çatışma Alanları}

Türkiye, yaklaşımını "kayıp nesiller” tartışması etrafında şekillendirmek yerine, kapsayıcı bir çerçeve uygulayarak "kazanılmış nesiller” söylemini vurgulamaktadır. ${ }^{61}$ Kant' in ifadesinde belirttiği gibi "yeryüzüne sınırsız şekilde yayılamayacak ve nihayet birbirlerinin varlıklarını hoş görmek zorunda olan” insanlar için, dünya çapında ebedi barışın koşullarının sağlanması önemlidir. Burada kastedilen toprak ayrımlarının yok edilmesi değildir. Aksine dostça ilişkilerin kurulduğu bir "dostluk hakkı"dır. “Düşmanliğın yerine konukseverliğin ikame edilmesidir.” ${ }^{2} \mathrm{Bu}$ düşünceyi destekler bir şekilde, bir katılımcı aşağıdaki ifadelere yer vermiştir:

"Ben 2010'da Türkiye'ye Urfa'ya geldim. Bir liseyi ziyaret ettim. Oradaki öğrenciler sanki uzayl gelmiş gibi karşıladılar, özel bir ağırlama vard. Çok güzel misafirperverlik göstermişlerdi. Güzel bir hafta yaşadim Urfa'da. Ondan sonra bir sene geçti. Tekrar Türkiye'ye geldim. Ama mülteci olarak geldim. Artık o gözle bakmiyorlardı. Farklı bir bakış açısıyla bakıyorlardı. "Bu mülteci, fakir, vatansız" gibi. Bizim saygimiz yerle bir oldu." (K7, Erkek, 24)

Görüldüğü üzere aslında sığınmacı öğrenciler özellikle yaşadığı yerlerde çeşitli önyargılarla ve hatta kimliklerini yaralayıcı ifadelerle karşılaşmaktadırlar. $\mathrm{Bu}$ durum gelecek açısından önemli sorunlar teşkil edebilmektedir. Charles Taylor bu durumu özsaygı yitimi ve kimlik sakatlanması olarak ele almaktadır. Ona göre ötekileştirilen insanların kendilerini değersiz görmeleri onların içinde bulundukları ezilmişlik konumunun sürdürülmesinde en önemli araç olarak karşımıza çıkmaktadır. ${ }^{63} \mathrm{Bu}$ durum gelecek açısından oldukça endişe vericidir.

${ }^{61}$ Ayselin Yildı, Integration of Refugee Students in European Higher Education Comparative Country Cases (İzmir: Yaşar Üniversitesi, 2019), 91.

${ }^{62}$ Zygmunt Bauman, Kapımızdaki Yabancılar, çev. Emre Barca (İstanbul: Ayrıntı Yayınları, 2019), 62-63.

${ }^{63}$ Charles Taylor, “Tanınma Politikası,” içinde Çokkültürcülük: Tanıma Politikası, ed. Amy Gutmann (İstanbul: Yapı Kredi Yayınları, 2018), 47, https://www.yapikrediyayinlari.com. tr/cokkulturculuk-tanima-politikasi.aspx 


\section{Hakan GÜLERCE ve Rukiye ÇORLU}

Belirsizlik başlığında belirtildiği gibi devlet politikaları, göç krizini tetiklemekle birlikte bireylerin kişisel sorumluluklarından uzaklaşmasına da neden olmaktadır. Bauman’a göre göç meselesinde, göçmenleri göz ardı etmek, duvarlar örmek, ayrıştırma, mesafeyi koruma vb. devlet politikaları "kısa vadede aldatıcı şekilde rahatlama sağlasa da gelecekteki bir patlama için patlayıcı depolamak” anlamına gelmektedir. Çünkü göçmenler ortak bir geleceği etkilemektedir. Dolayısıyla bu tehlikeyi büyütmek yerine azaltmak gerekir ki bundan çıkışı sağlayacak tek yol "ayrışma eğilimlerini reddetmek"tir. Bunun nasıl yapılacağını ise kendisi şöyle ifade etmektedir:

"Zamanımizin "tek gezegen, tek insanlik" gerçekliğinin meseleleriyle yüzleşmeyi reddetmek, kendimizi temize çıkarmak ve asap bozucu farklilı, benzeşmezlik ve kendini dayatan yabancılaşmalardan

Üsküdar University Journal of Social Sciences, 2021; issue: 12 , 71-106 kendimizi ayırmak yerine, onlarla yakın ve gitgide artan ölçüde samimi temaslar kuracak firsatlar aramaliyiz. Umulur ki bu, teşvik edilen ve tasarlanan bölünme yerine ufukların kaynaşmasıyla sonuçlansin." 64

Çalışmada yapılan odak grup görüşmesinde öğrencilere neler yapılması gerektiği üzerine fikirleri sorulduğunda aşağıdaki ifadelere yer vermişlerdir:

"Kendimizi tanıtmalıyı. Bizi tanımadıkları için böyle davranışlar var. Aslında bize görev düşüyor. Bizim kendimizi tanıtmamız gerekiyor." (K1, Kadın, 22)

"Suriyeli bir arkadaşı olmayanın Suriyeliler hakkında bilgisi yok, olumsuz şeyler konuşuyor. Suriyeli arkadaşı olan, arkadaşı olmayanlardan bir bilgi öğrenir. Böylece herkes ögrrenecek kim olduğumuz? Ne yaptığımızı? Bizim paramızı nerden kazandığımızı? Üniversiteye nasıl girdiğimizi? Herkes doğrusunu öğrenecek. Ben kimseden hiçbir şey istemiyorum. Sadece güler bir yüzle karşılanmak istiyorum. Biriyle konuşurken kızgin gibi konuşmasın ya da hiç konuşması daha iyi. Ama konuşunca bir empati göstersin. Sonuçta

${ }^{64}$ Bauman, Kapımızdaki Yabancılar, 21. 


\section{Yükseköğretimdeki Suriyeli Sığınmacı Öğrenciler: \\ Uyum ve Çatışma Alanları}

ben keyfimden gelmedim, zorla geldim. Insanlar empati gösterse her şey düzeltilir bence. Ama onlarm bizi kabul etmeleri de bir empati, bir empati işareti." (K7, Erkek, 24)

"Kadınlar için dil kursu, örgü kursu gibi kurslar açılmal, mesleki eğitimler verilmeli. Böyle yapılırsa kadınlar arasındaki önyargılar kırılmış olabilir. Erkekler için de olabilir, mesleki eğitimler verilebilir, iş konusunda toplantılar yapılabilir. Öğrenciler için de daha fazla etkinlik yapılabilir. Üniversitede biz baya etkinlik yaptık. Pek çoğuna katıldım. Bizim hakkımızda gerçeklerin söylenmesi lazım. Suriyeli iyi bir şey yapinca çok konuşulmuyor. Ama kötü bir şey yapinca yapan herkes onu konuşuyor. "Suriyeliler şöyle yaptı" gibi görünüyor haberde. Bu genellemelerin kalkması lazım." (K8, Kadın, 23)

"Halk daha fazla bilgilendirilmeli. Çünkü evdekilerin dışarıda ne olduğundan haberi yok. Üniversite öğrencisi bazı şeyleri biliyor, bazıları yanlış biliyor, bazıları doğru biliyor." (K9, Erkek, 19)

Görüldüğü gibi sığınmacı gençler açısından bakıldığında en büyük sorunun ön yargıların kırılmasında yattığını görmekteyiz. Ön yargıların kırılmasına, diğer bir ifadeyle zihnimizde inşa ettiğimiz duvarların yıkılmasına yönelik yapılacak her çalışma büyük anlam ifade etmektedir. $\mathrm{Bu}$ durumu Deniz Ülke Arıboğan, "Eğer köprü mimarları, duvarcı ustalarını yenemezse, 'geleceğimiz' bu duvarların ardında inşa edilecek." ${ }^{65}$ ifadesiyle çok güzel özetlemektedir.

\section{Sonuç}

Suriye'de devam eden iç karışıklıklar nedeniyle yüzbinlerce insan sınır ötesi göçe maruz kalarak yerlerinden edilmiştir. Suriye'den Türkiye'ye doğru gerçekleşen kitlesel zorunlu göçün toplumsal, sosyal, ekonomik, siyasi ve güvenlik bağlamında birçok etkisi bulunmaktadır. Özellikle yaşanan bu kitlesel göç ani bir insani karşılaşmayı da beraberinde getirmiş

${ }^{65}$ Deniz Ülke Arıboğan, Duvar: Tarih Geri Dönüyor, (İstanbul: İnkılap, 2017). 


\section{Hakan GÜLERCE ve Rukiye ÇORLU}

ve çeşitli uyum ve çatışma alanları ortaya çıkarmıştır. Bu süreçte toplumun farklı aktörleri farklı şekilde rol almaktadır. Çalışmada bu karşılaşma ve birlikte yaşama süreci Harran Üniversitesi öğrencileri üzerinden değerlendirilmiştir. Yapılan odak grup görüşmelerinde yükseköğretimdeki Suriyeli öğrencilerin sosyal deneyimleri ve karşılaş̧ıkları sorunlar üzerine Zygmunt Bauman'ın kabullenme, belirsizlik, toplumsal etkileşim, etiketleme ve ötekileştirme kavramları üzerinden bir analiz yapılmıştır. $\mathrm{Bu}$ bağlamda bazı Suriyeli öğrencilerin çeşitli alanlarda sosyal dışlanma, ötekileştirme, damgalanma ve etiketlenmeye maruz kaldıkları ortaya çıkmıştır. Ancak yine de birçok alanda uyum ve dahil etme pratiklerinin de yaşandığı tespit edilmiştir. Suriyeli öğrencilerin topluma dâhil olma ve birlikte yaşama isteklerinin yüksek olduğu, birlikte yaşama kültürünün

Üsküdar University Journal of Social Sciences, 2021; issue: 12 , 71-106 inşasında aktif rol almak istedikleri sonucuna varılmıştır.

Suriyeli öğrencilerin okul içerisinde özellikle arkadaşları tarafından onları da memnun eden bir toplumsal kabul yaşadıkları ortaya çıkmıştır. Ancak okulda yaşadıkları bu kabul süreci ikamet ettikleri semtlerde farklılaşmaktadır.Bu da onlarıçeşitliaçılardan olumsuz etkileyebilmektedir. $\mathrm{Bu}$ durum da onların akranlarından ziyade onları tanımayan çevrelerce dışlandıklarını göstermektedir. Bunun sebebi de toplumun genel olarak Suriyeli sığınmacıları yeterince tanımaması ve halk arasındaki doğru bilinen yanlışların yaygın olması ile açıklanmaktadır.

Belirsizlik, öğrencilerin sosyal uyum sürecinde karşılaştıkları önemli sorunlardan birisidir. Bir öğrencinin geleceği hakkında bir fikir sahibi olamaması onun için hem kimlik inşasında hem de toplumsal uyum bakımından yaralayıcı olabilmektedir. Türkiye'de bir yaşam, üçüncü bir ülkeye gidiş veya kendi ülkelerine geri dönüşten hiçbirisinin belirli olmaması onları çok sancılı bir belirsizlik sürecine itmektedir. Onlar bir taraftan topluma dahil olup öğrenimlerini devam ettirmeye çalışırken diğer taraftan büyük bir belirsizlikle mücadele etmektedirler. Bu arafta olma durumu da onların ve yerel halkın sosyal uyum süreçlerine olumsuz yansımaktadır. 
Yükseköğretimdeki Suriyeli Sığınmacı Öğrenciler:

Uyum ve Çatışma Alanları

Öğrencilerin yaşadıkları diğer bir sosyal sorun ise toplumsal etkileşimin yeterince güçlü olmamasıdır. Özellikle sığınmacı ve yerel öğrencilerin sadece kendileri gibi sığınmacı veya yerel arkadaşları ile iletişim kurmaları sosyal uyumun önündeki engellerden biridir. Aslında bu durum da karşllıklı düşünülmelidir. Hem Türk hem de Suriyeli öğrencilerin karşlıklı olarak iletişim kurma istekliliklerinin yeterli düzeyde olmadığı gözlenmektedir. Bunun birçok nedeni olabilir. Bu nedenlerin en başında önyargılar, dil problemi ve çeşitli bağlamlarda etiketleme ve ötekileştirme olarak ortaya çıkmaktadır.

Öncelikle etiketleme ve ardından kaçınılmaz olarak gelen ötekileştirme sürecinin, sığınmacı öğrencilerin sosyal uyum süreçlerini ve özellikle psikolojik sağlıklarını önemli ölçüde olumsuz etkilediği ortaya çıkmıştır. Ötekileştirme aslında içinde önemli tehlikeleri de barındırmaktadır. Bu durum yer yer çeşitli şiddet biçimlerine dönüşebilmektedir.

Sonuç olarak birlikte yaşamanın yolu duvarlar yerine köprülerin inşa edilmesinden geçmektedir. Bu ise; göçmenlerin ve ev sahibi toplumların uyumiçerisinde, birbirlerine “Hoşgeldin!" demektenkorkmadığı bir dünya ile mümkün olabilir. Öyleyse bu çalışmadan; sığınmacı ögrencilerin uyum sorunlarının azaltılacağı, birlikte yaşama kültürünün güçlendirileceği ve kaynaşmanın sağlanabileceği çalışmalara her zamankinden daha fazla ihtiyaç olduğu sonucu çıkmaktadır.

\section{KAYNAKÇA}

Açıkel, Nihal. “İstanbul'daki Suriyeli Üniversite Gençliği Üzerine Nitel Bir Araştırma.” Yüksek Lisans Tezi, İstanbul Üniversitesi, 2019.

Agier, Michel. Aux bords du monde, les réfugiés. Paris: Flammarion, 2002.

Ağca-Varoğlu, F. Güzin. "Almanya’da Yüksek Nitelikli Göçmenlerin Gündelik Hayat Deneyimleri ve Baş Etme Süreçleri”. Journal of Economy Culture and Society, Sayı: 62 (25 Arallk 2020): 23-46, https://doi. org/10.26650/JECS.2019-0124 


\section{Hakan GÜLERCE ve Rukiye ÇORLU}

Arıboğan, Deniz Ülke. Duvar: Tarih Geri Dönüyor. İstanbul: İnkılap, 2017.

Bauman, Zygmunt. Iskarta Hayatlar \& Modernite ve Safraları. Çeviren Osman Yener. İstanbul: Can Yayınları, 2018.

------. Kapımızdaki Yabancılar. Çeviren Emre Barca. İstanbul: Ayrıntı Yayınları, 2019.

------. Kimlik. Çeviren Mesut Hazır. Ankara: Heretik, 2017.

------. Sosyolojik Düşünmek. Çeviren Abdullah Yılmaz. İstanbul: Ayrıntı Yayınları, 2015.

Bauman, Zygmunt, ve Stanislaw Obirek. Dünyaya ve Kendimize Dair. Çeviren Burcu Halaç. İstanbul: Ayrıntı Yayınları, 2018.

Üsküdar University Journal of Social Sciences, 2021; issue: 12 , 71-106

Binti, Hilal. "Ötekileştirme." Avrasya Sosyal ve Ekonomi Araştırmaları Dergisi 4, Sayı: 3 (1 Mart 2017): 1-9.

Cebeci, Suat. Bilimsel Araştırma ve Yazma Teknikleri. İstanbul, 2002.

Creswell, John W. Nitel Araştırma Yöntemleri: Beş Yaklaşıma Göre Nitel Araştırma ve Araştırma Deseni. Ankara, 2014.

Çopur, Ahmet, ve Muammer Demirel. "Suriyeli Mültecilerin Yükseköğrenim Sorunu: Göç Süreci ve Sonrası”, 2016, https://avesis. uludag.edu.tr/yayin/74a07545-d673-494d-b498-c7d13b2cd7a1/egitimbilimlerinde-yenilikler-ve-nitelik-arayisi

Erdoğan, M. Murat. Suriyeliler Barometresi 2019, Suriyelilerle Uyum İçinde Yaşamın Çerçevesi. Ankara: Orion Kitabevi, 2020.

Ertong Attar, Günnur ve Deniz Küçükşen. "Somehow Familiar but Still a Stranger: Syrian Students in Turkish Higher Education." Journal of International Migration and Integration 20, Sayı: 4 (1 Kasim 2019): 10411053, https://doi.org/10.1007/s12134-018-00647-8

Geçici Koruma. “Göç İdaresi Genel Müdürlüğü,” 18 Aralık 2020. https:// www.goc.gov.tr/gecici-koruma5638 


\section{Yükseköğretimdeki Suriyeli Sığınmacı Öğrenciler: \\ Uyum ve Çatışma Alanları}

Gök, Naim. "Suriye Krizi’nin Türkiye'ye Yansımaları (2011-2017)." Üsküdar Üniversitesi Sosyal Bilimler Dergisi. Sayı: 8 (Mayıs 2019): 77144.

Gülerce, Hakan. "Göç ve Belirsizlik: Eşleri Kayıp Suriyeli Sığınmacı Kadınlar.” İnsan \& Toplum 10, Sayı: 3 (Eylül 2020): 217-221, https:// doi.org/10.12658/V0001

“Güvenlik Terimleri Sözlügüu.” İçinde Etiketleme Teorisi. Ankara: T.C. İçişleri Bakanlı̆̆ı Kamu Düzeni ve Güvenliği Müsteşarlığı 2017.

Karadağ, Nazife. "Yükseköğretimde Uluslararasılaşma Bağlamında Türkiye'de Eğitim Gören Suriyeli Öğrenciler Üzerine Bir Araştırma," Journal of Turkish Studies 11, Sayı: 19 (1 Ocak 2016): 477-490, https:// doi.org/10.7827/TurkishStudies.11155

Kaya, Özgür Salih. "Geçici Koruma Statüsünde Bulunan Suriyeli Üniversite Öğrencilerinin Göç Sürecindeki Uyum Yaşantıları.” Yüksek Lisans Tezi, Hacettepe Üniversitesi, 2019.

Ökten, Şevket. "Zorunlu Göç Zor(un)lu Kabul: Ceylanpınar Afgan Göçmenleri Üzerine Sosyolojik Bir Araştırma." Harran Üniversitesi İlahiyat Fakültesi Dergisi 28, Say1: 28 (01 Aralık 2012): 171-186.

Robert, Philippe, Olivier Mongin, Marc-Olivier Padis, ve Monique Seyler. "Une généalogie de l'insécurité contemporaine: Entretien avec Philippe Robert.” Esprit, Sayı: 290 (12) (2002): 35-58.

Sennett, Richard. Yabancl: Sürgün Üzerine İki Deneme. Çeviren Tuncay Birkan. İstanbul: Metis Yayıncıllk, 2017.

Shakespeare, William. Venedik Taciri. Çeviren Bülent Bozkurt. İstanbul: Remzi Kitabevi, 2013. 


\section{Hakan GÜLERCE ve Rukiye ÇORLU}

Talwasa, Sanaa. 'Seeking a 'Better Life' in Turkey: Afghan Refugees' International Human Rights Condition in Turkey.” Üsküdar Üniversitesi Sosyal Bilimler Dergisi, Sayı: 11 (Kasım 2020): 245-274, http://doi. org/10.32739/uskudarsbd.6.11.76

Taylor, Charles. “Tanınma Politikası.” İçinde Çokkültürcülük: Tanıma Politikası, editör Amy Gutmann, (İstanbul: Yapı Kredi Yayınları, 2018), 46-93. https://www.yapikrediyayinlari.com.tr/cokkulturculuk-tanimapolitikasi.aspx

Uçar, Rukiye. "Intercultural communication and adaptation of Syrian University students: A study at a foundation university in Istanbul.” Yüksek Lisans Tezi, Yıldız Teknik Üniversitesi, 2019.

Üsküdar University Journal Yıldırım, Ali, ve Hasan Şimşek. Sosyal Bilimlerde Nitel Araştırma Yöntemleri. Ankara: Seçkin Yayıncılık, 2017.

Yildı, Ayselin. Integration of Refugee Students in European Higher Education Comparative Country Cases. İzmir: Yaşar Üniversitesi, 2019.

“Yükseköğretim Bilgi Yönetim Sistemi.” Erişim 26 Aralık 2020. https://istatistik.yok.gov.tr/ 